\title{
Exercise-induced myocardial ischaemia on scintigraphy despite $\beta$-blocker therapy in patients with an anomalous origin of the right coronary artery coursing between the aorta and pulmonary artery
}

\author{
Gian Piero Carboni, ${ }^{1}$ Pietro Sedati ${ }^{2}$ \\ ${ }^{1}$ Department of Nuclear Cardiology, Università Campus Bio-Medico, Rome, Italy \\ ${ }^{2}$ Department of Radiology, Università Campus Bio-Medico, Rome, Italy
}

Correspondence to Professor Gian Piero Carboni, g.carboni@unicampus.it

\section{DESCRIPTION}

In February 2012, a 60-year-old man presented to us with a positive exercise test for ST-depression, which was performed before beginning sports activity. Rest/stress thallium-201 single-photon emission cardiac tomography (SPECT) revealed inferior and lateral wall reversible defects (ischaemia) and a painless ST-depression at peak during a bicycle maximal exercise test. Cardiac tomography (CT) documented an anomalous origin of the right coronary artery (ARCA) arising from the left sinus of Valsalva with an extramural course between the aorta and the pulmonary artery (figure 1). The aetiology of myocardial ischaemia in ARCA is multifactorial and is caused by the transient coronary flow reduction elicited by the systolic compression of the ARCA that is produced by the

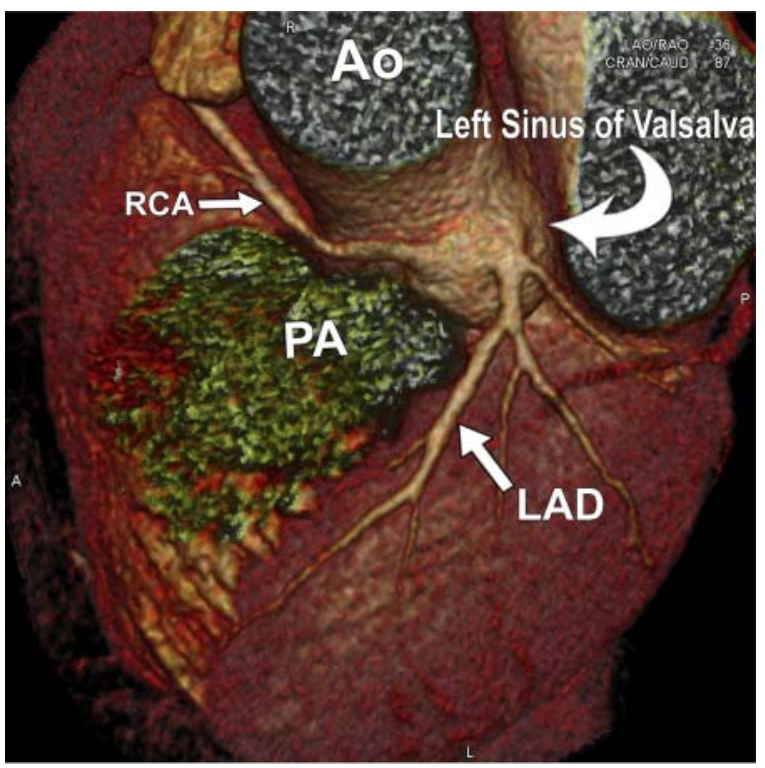

Figure 1 Volume-rendered CT images indicates extramural anomalous origin of the right coronary artery with interarterial course between the aortic root $(\mathrm{Ao})$ and the pulmonary artery $(\mathrm{PA})$; right coronary artery $(\mathrm{RCA})$ reduced calibre. Left anterior descending coronary artery (LAD). great arteries at peak exercise. ${ }^{1}$ The ARCA stenosis was about $40 \%$ on CT as confirmed by the invasive angiogram. The SPECT results suggested, however, the presence of a dynamic stenosis. The patient was treated with $200 \mathrm{mg}$ of metoprolol daily for 2 months, and rest/stress thallium-201 SPECT was then repeated with the same techniques. Metoprolol reduced the myocardial oxygen consumption, which was indirectly measured by the peak exercise double product, but the ischaemic burden on SPECT did not change significantly from the basal values (figure 2). A failure to reduce the ARCA proximal systolic compression after $\beta$-blocker treatment may result in myocardial ischaemia, ${ }^{2}$ and, thus, in increased vulnerability to life-threatening arrhythmias, myocardial infarction and sudden death during daily activities. Surgical management is usually recommended in patients with symptoms or exercise-induced myocardial ischaemia. ${ }^{3}$

\section{Learning points}

- Myocardial ischaemia may be caused by anomalous origin of the right coronary artery with interarterial course.

- Cardiac CT has been established as an excellent non-invasive test to identify and classify congenital coronary anomalies.

- Rest/stress single-photon emission cardiac tomography is a valid instrument to detect the efficacy of the medical treatment.

Competing interests None.

Patient consent Obtained.

\section{REFERENCES}

1. Gersony WM. Management of anomalous coronary artery from the contralateral coronary sinus. J Am Coll Cardiol 2007;50:2083-4.

2. Vincelj J, Todorović N, Marusić P, et al. Anomalous origin of the left coronary artery from the right sinus of Valsalva in a 62-year-old woman with unstable angina pectoris: a case report. Int J Cardiol 2010;142:e35-7.

3. Reddy RC, Takahashi M, Beckles DL, et al. Anomalous right coronary artery from the left sinus: a minimally invasive approach. Eur J Cardiothorac Surg 2012;41:287-90. 


\section{BMJ Case Reports}
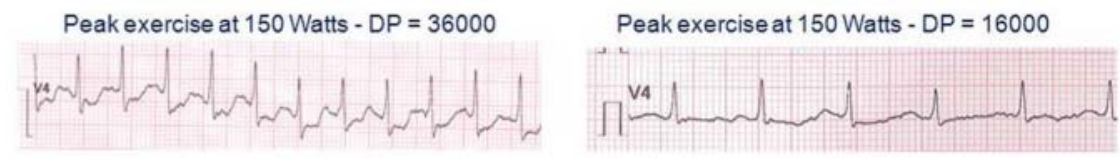

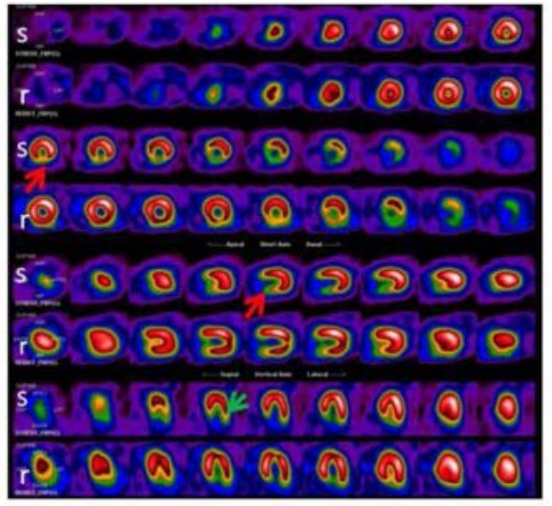

SPECTA

Peak exercise without $\beta$-blockers

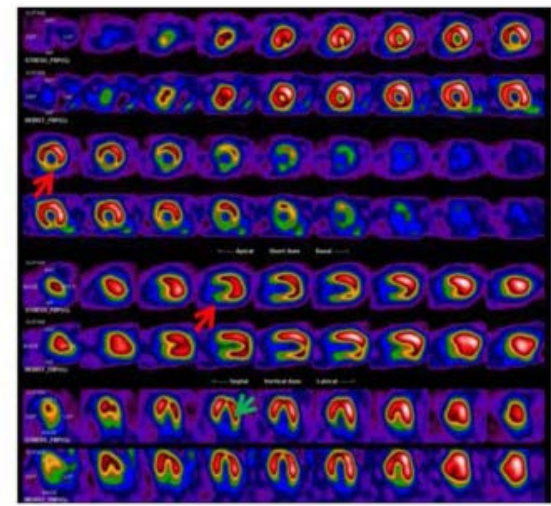

SPECT B

Peak exercise on $\beta$-blockers

Figure 2 Stress (s) rest $(r)$ thallium-201 single-photon emission cardiac tomography before (A) and after (B) therapy. Reversible perfusion defects, inferior (red arrows) and lateral (green arrows).

This pdf has been created automatically from the final edited text and images.

Copyright 2012 BMJ Publishing Group. All rights reserved. For permission to reuse any of this content visit http://group.bmj.com/group/rights-licensing/permissions.

BMJ Case Report Fellows may re-use this article for personal use and teaching without any further permission.

Please cite this article as follows (you will need to access the article online to obtain the date of publication).

Carboni GP, Sedati P. Exercise-induced myocardial ischaemia on scintigraphy despite $\beta$-blocker therapy in patients with an anomalous origin of the right coronary artery coursing between the aorta and pulmonary artery. BMJ Case Reports 2012;10.1136/bcr-2012-007146, Published XXX

Become a Fellow of BMJ Case Reports today and you can:

- Submit as many cases as you like

- Enjoy fast sympathetic peer review and rapid publication of accepted articles

- Access all the published articles

- Re-use any of the published material for personal use and teaching without further permission

For information on Institutional Fellowships contact consortiasales@bmjgroup.com

Visit casereports.bmj.com for more articles like this and to become a Fellow 